\title{
THE FIRST LIST OF AMPHIBIANS AND REPTILES FROM SOC SON WATERSHED PROTECTION FOREST, HA NOI CITY, VIETNAM
}

\author{
Tran Thanh Tung ${ }^{1}$, Le Trung Dung, \\ ${ }^{1}$ Vinh Phuc College, Trung Nhi street, Phuc Yen City, Vinh Phuc Province \\ ${ }^{2}$ Ministry of Education and Training, 35 Dai Co Viet Street, Ha Noi City
}

Received 30 September 2020, accepted 16 March 2021

\begin{abstract}
Based on a new herpetological collection from four field surveys conducted in the Soc Son Watershed Protection Forest, Ha Noi City, from March 2017 to April 2018. We herein provide the first list of 42 species of amphibians and reptiles, in which, 12 species are newly recorded for the herpetofauna of Ha Noi City. In addition, morphological characters of these species are also provided. In terms of conservation concern, two species are listed in the IUCN Red List (2020), five species are listed in the Vietnam Red Data Book (2007), and two species are listed in the Governmental Decree No 06/2019/ND-CP.
\end{abstract}

Keywords: Amphibians, checklist, distribution, morphology, reptiles, Ha Noi.

Citation: Tran Thanh Tung, Le Trung Dung, 2021. The first list of amphibians and reptiles from Soc Son watershed protection forest, Ha Noi City, Vietnam. Academia Journal of Biology, 43(1): 61-76. https://doi.org/10.15625/2615$9023 / 14450$

*Corresponding author email: letrungdung_sp@hnue.edu.vn

C2021 Vietnam Academy of Science and Technology (VAST) 


\section{INTRODUCTION}

The herpetofauna is not only an important component of the global biodiversity, but also serves as important bioindicators for ecosystem health (e. g., Marsili et al. 2009). They are being predators at the upper end of trophic pyramids and due to their territoriality, and limited locomotion, reptiles and amphibians cannot evade disturbances, and active recolonization after local extinction is very slow. Evergreen forests, rehabilitation forests, and protective forests play an important role in protecting these sensitive organisms.

The Soc Son Watershed Protection Forest (WPF) was established in 2008 by the Decision No. 2100/QD-UB of the People's Committee of Ha Noi with an area of 4557 ha. The major habitat of this area is secondary forest of small hardwoods and shrub (People's Committee of $\mathrm{Ha}$ Noi 2008). However, nothing is known about biodiversity of the Soc Son WPF, including the herpetofauna. No list of amphibia or reptile species has been provided for this area in previous studies.

Based on the results of field surveys, photo records, and collected specimens, this article provides a summary of new herpetofaunal records from Soc Son WPF, including six newly recorded species for the herpetofauna of Hanoi City.

\section{MATERIALS AND METHODS}

Four field surveys were conducted in Soc Son WPF, Soc Son District, Ha Noi City, Vietnam (Fig. 1), from 27 March 2017 to 4 April 2018 by Tung Thanh Tran, Tinh Xuan Dao, and Anh Tuan Dao (Tran et al.). Survey transects were set up along the streams, pools, small ponds and along the forest paths. Specimens were euthanized in a closed vessel with a piece of cotton wool containing ethyl acetate (Simmons, 2002), fixed in $85 \%$ ethanol for 10 hours, and then transferred to $70 \%$ ethanol for permanent storage. Frog and snake specimens referred to in this paper have been deposited in the collections of the Vinh Phuc College (VPC), Vinh Phuc Province. Photos of specimens were taken by Dung Trung Le with Canon $7 \mathrm{D}$ camera in the laboratory.

Taxonomic identifications were based on Smith (1943), Campden - Main (1970), Ohler et al. (2002), Nguyen et al. (2005), Nguyen (2007), David et al. (2008), and Das (2010), Hetch et al. (2013), Le et al. (2014), Le et al. (2015), and Le et al. (2018). Species names followed Nguyen et al. (2009), Frost (2020), and Uetz et al. (2019). Sex was identified based on external sexual characters, and if required, from gonad inspection after dissection.

Measurements were taken with dial callipers to the nearest $0.1 \mathrm{~mm}$, except for body and tail lengths of reptiles, which were measured with a measuring tape to the nearest $1 \mathrm{~mm}$.

For amphibians, abbreviations are as follows: SVL: snout-vent length; HL: head length, from posterior corner of mandible to tip of snout; HW: maximum head width, at the angle of jaws; SL: distance from anterior corner of eye to tip of snout; ED: eye diameter, from anterior corner to posterior corner of eye; NEL: distance from anterior corner of eye to posterior edge of nostril; SNL: distance from anterior edge of nostril to tip of snout; IN: internarial distance; IOD: minimum distance between upper eyelids; UEW: maximum width of upper eyelid; TYD: maximum tympanum diameter; TYE: distance between anterior margin of tympanum and posterior corner of eye; FLL: forelimb length, from elbow to base of outer tubercle; HAL: hand length, from base of outer palmar tubercle to tip of third finger; FL: thigh length, from vent to knee; TL tibia length.

For reptiles, abbreviation are as follows: SVL: snout- vent length, from tip of snout to anterior margin of cloaca; TaL: tail length, from posterior margin of cloaca to tip of tail; HL: head length, from tip of snout to posterior margin of parietal; HW: head width, at the widest point of temporal region; FIL: forelimb length, from anterior junction of forelimb and body wall to the tip of fourth finger, with the limb held at right angles to 
the body; HIL: hind limb length, anterior junction of hind limb and body wall to the tip of fourth toe, with the limb held at right angle to the body. The number of ventral scales was counted according to Dowling (1951).

asl: above sea level. Bilateral scale counts were given as left/right.

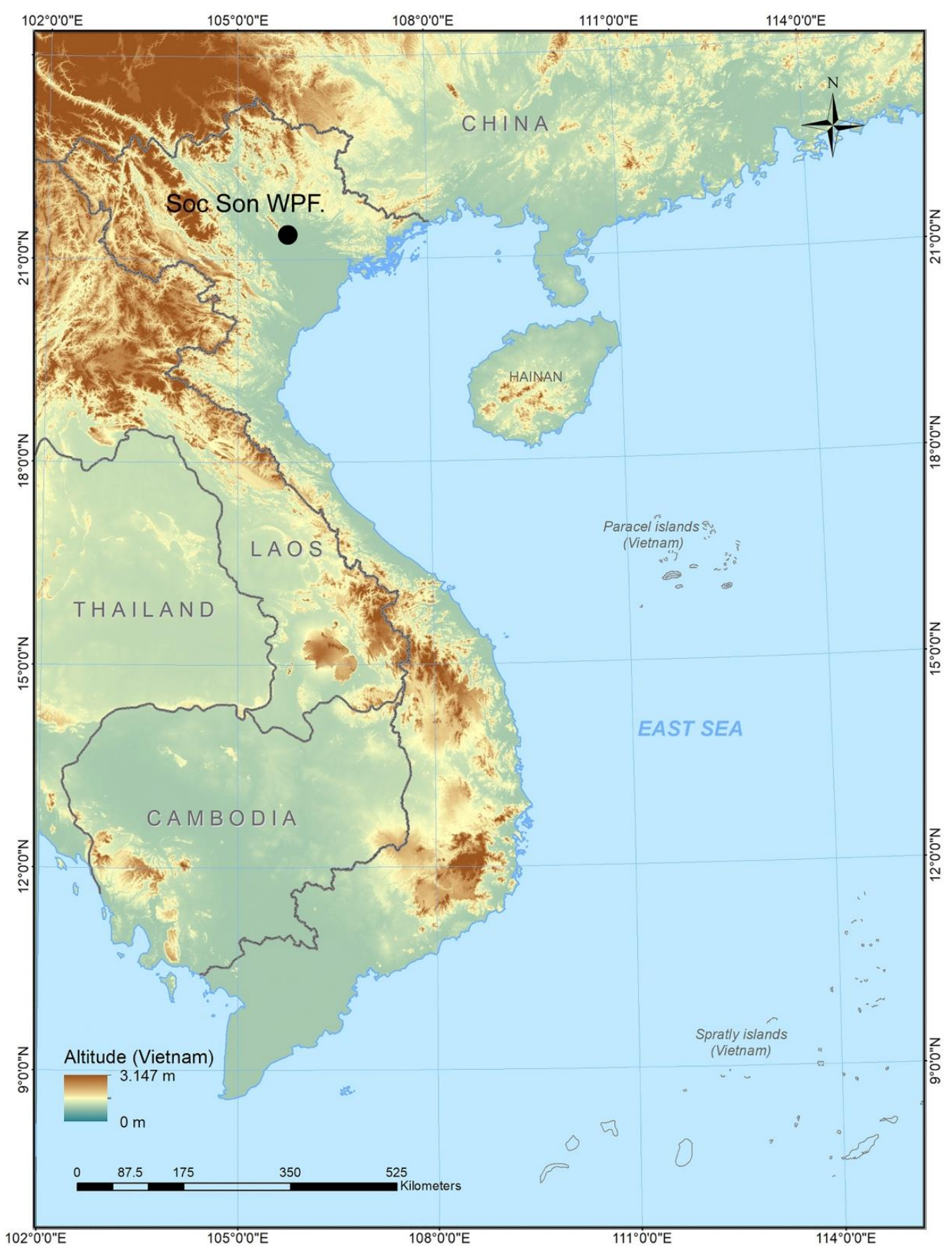

Figure 1. Map showing the geographical location of Soc Son Watershed Protection Forest (black circle), Ha Noi, Vietnam 


\section{RESULTS}

A total of 42 species of amphibians and reptiles belonging to 17 families and two orders was recorded from Soc Son WPF, comprising 10 species of amphibians and 32 species of reptiles (Table 1). Colubridea is the most diverse family with nine recorded species, followed by Elapidae (five species), Microhylidae (four species), Scincidae (four species), and the other families from one to three species each.

Table 1. List of amphibian and reptile species recorded from Soc Son WPF, Hanoi City, Vietnam. Decree 06 (2019) = Governmental Decree No 06/2019/ND-CP by the Government of

Vietnam on the management of endangered wild ora and fauna. Group IB: prohibited exploitation and use for commercial purpose and Group IIB: limited exploitation and use for commercial purpose; VNRB (2007) = Vietnam Red Data Book. Part I. Animals. Descriptions of nationally endangered species of wild animals. $\mathrm{CR}=$ Critically Endangered, $\mathrm{EN}=$ Endangered, VU $=$ Vulnerable; IUCN $(2020)=$ The IUCN Red List of Threatened Species. CR $=$ Critically Endangered, $\mathrm{EN}=$ Endangered, $\mathrm{VU}=$ Vulnerable

\begin{tabular}{|c|c|c|c|c|c|}
\hline No. & Species & English name & $\begin{array}{l}\text { ఏ్రి } \\
\text { d } \\
z \\
己 \\
己\end{array}$ & 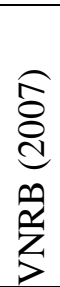 & 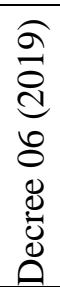 \\
\hline & AMPHIBIA Gray, 1825 & & & & \\
\hline & ANURA Fischer von Waldheim, 1813 & & & & \\
\hline & I. Bufonidae & & & & \\
\hline \multirow[t]{2}{*}{1} & $\begin{array}{l}\text { Duttaphrynus melanostictus (Schneider, } \\
\text { 1799) }\end{array}$ & Black- spined toad & & & \\
\hline & II. Dicroglossidae & & & & \\
\hline \multirow[t]{2}{*}{2} & $\begin{array}{l}\text { Limnonectes bannaensis Ye, Fei, Xie, and } \\
\text { Jiang, } 2007\end{array}$ & $\begin{array}{l}\text { Banna large-headed } \\
\text { frog }\end{array}$ & & & \\
\hline & III. Microhylidae & & & & \\
\hline 3 & Microhyla berdmorei (Blyth, 1856) & $\begin{array}{l}\text { Berdmore's narrow- } \\
\text { mouthed frog }\end{array}$ & & & \\
\hline 4 & M. fissipes (Boulenger, 1884) & Ornate pigmy frog & & & \\
\hline 5 & M. picta Schenkel, 1901 & Painted rice frog & & & \\
\hline \multirow[t]{2}{*}{6} & M. pulchra (Hallowell, 1861) & Guangdong rice frog & & & \\
\hline & IV. Ranidae & & & & \\
\hline \multirow[t]{2}{*}{7} & Hylarana erythraea (Schlegel, 1837) & Green paddy frog & & & \\
\hline & V. Hylidae & & & & \\
\hline \multirow[t]{2}{*}{8} & Hyla simplex Boettger, 1901* & Annam treefrog & & & \\
\hline & VI. Rhacophoridae & & & & \\
\hline 9 & Polypedates mutus (Smith, 1940) & Burmese whipping frog & & & \\
\hline \multirow[t]{5}{*}{10} & Rhacophorus rhodopus Liu \& Hu, 1960* & Red-webbed treefrog & & & \\
\hline & REPTILIA Laurenti, 1968 & & & & \\
\hline & SQUAMATA Oppel, 1811 & & & & \\
\hline & SAURIA Macartney, 1803 & & & & \\
\hline & I. Agamidae & & & & \\
\hline
\end{tabular}




\begin{tabular}{|c|c|c|c|c|c|}
\hline 11 & Acanthosaura lepidogaster (Cuvier, 1829) & Scale bellied tree lizard & & & \\
\hline 12 & Calotes versicolor (Daudin, 1802)* & Oriental garden lizard & & & \\
\hline \multirow[t]{2}{*}{13} & Draco maculatus (Gray, 1845) & Spotted flying lizard & & & \\
\hline & II. Gekkonidea & & & & \\
\hline \multirow[t]{2}{*}{14} & Gekko palmatus Boulenger, 1907 * & Palm gecko & & & \\
\hline & III. Scincidae & & & & \\
\hline 15 & Eutropis longicaudatus (Hallowell, 1857) & Long tailed mabuya & & & \\
\hline 16 & Sphenomorphus indicus (Gray, 1853)* & Indian forest skink & & & \\
\hline \multirow[t]{3}{*}{18} & Tropidophorus baviensis (Bourret, 1939) & Bavi water skink & & & \\
\hline & SERPENTES Linnaeus, 1758 & & & & \\
\hline & Xenopeltidae & & & & \\
\hline \multirow[t]{2}{*}{19} & Xenopeltis unicolor Reinwardt, 1827 & Sunbeam snake & & & \\
\hline & IV. Colubridea & & & & \\
\hline 20 & Calamaria septentrionalis Boulenger, 1890 & Hong kong dwarf snake & & & \\
\hline 21 & Cyclophiops multicinctus (Roux, 1907) & $\begin{array}{l}\text { Many-banded green } \\
\text { snake }\end{array}$ & & & \\
\hline 22 & Coelognathus radiatus (Boie, 1827) & Copperhead racer & & VU & \\
\hline 23 & Elaphe taeniura (Cope, 1861)* & Beauty snake & & & \\
\hline 24 & Gonyosoma boulengeri (Mocquardt, 1897) & Rhino rat snake & & & \\
\hline 25 & Lycodon subcinctus Boie, 1827 & $\begin{array}{l}\text { Malayan banded wolf } \\
\text { snake }\end{array}$ & & & \\
\hline 26 & Oligodon chinensis (Günther, 1888)* & Chinese kukri snake & & & \\
\hline 27 & O. taeniatus (Günther, 1861)* & Striped kukri snake & & & \\
\hline \multirow[t]{2}{*}{28} & Ptyas korror (Shlegel, 1837) & Indochinses rat snake & & EN & \\
\hline & \begin{tabular}{|l|} 
V. Natricidae \\
\end{tabular} & & & & \\
\hline 29 & Sinonatrix percarinata (Boulenger, 1899)* & Eastern water snake & & & \\
\hline \multirow[t]{2}{*}{30} & Xenochrophis flavipunctatus (Hallowell, 1861) & Yellow spotted keelback & & & \\
\hline & VI. Pareatidae & & & & \\
\hline 31 & Pareas carinatus (Boie, 1828$)^{*}$ & Keeled slug snake & & & \\
\hline \multirow[t]{2}{*}{32} & P. margaritophorus (Jan, 1866) & White spotted slug snake & & & \\
\hline & IV. Pseudoxenodontidae & & & & \\
\hline \multirow[t]{2}{*}{33} & Pseudoxenodon bambusicola (Vogt, 1922) & Bamboo snake & & & \\
\hline & VII. Homalopsidae & & & & \\
\hline \multirow[t]{2}{*}{34} & Hypsiscopus plumbea (Boie, 1827) & Plumbeous water snake & & & \\
\hline & VIII. Elapidae & & & & \\
\hline 35 & Bungarus candidus (Linnaeus, 1758)* & Blue krait & & & \\
\hline 36 & B. fasciatus (Schneider, 1801) & Banded krait & & EN & \\
\hline 37 & B. multicinctus Blyth, 1861 & Many banded krait & & & \\
\hline 38 & Naja atra Cantor, 1842 & Chinese cobra & VU & EN & IIB \\
\hline \multirow[t]{2}{*}{39} & Ophiophagus hannah (Cantor, 1836) & King cobra & VU & $\mathrm{CR}$ & IB \\
\hline & IX. Viperidae & & & & \\
\hline 40 & Protobothrops mucrosquamatus (Cantor, 1839) & Chinese habu & & & \\
\hline 41 & Trimeresurus albolabris Gray, 1842 & White lipped pitviper & & & \\
\hline 42 & T. stejnegeri Schmidt, $1925^{*}$ & Chinese green tree viper & & & \\
\hline
\end{tabular}

Note: $*$ new provincial records. 
New records of amphibians and reptiles for the herpetofauna of Hanoi City

\section{AMPHIBIA}

Family HYLIDAE

Hyla simplex Boettger, 1901/Annam Treefrog (Fig. 2a, 2b)

Specimens examined $(n=2)$. Two adult males (VPC.2018.80, 81), collected on 25 May 2017 near Dong Lon sector, Soc Son WPF $\left(21.3208^{\circ} \mathrm{N}, 105.8052^{\circ} \mathrm{E}\right.$, elevation 285 $\mathrm{m}$ asl.).

Description. Morphological characters of the specimens from Hanoi agreed well with descriptions by Orlov et al. (2002) and Nguyen et al. (2005): SVL 32.7-34 mm in males; head longer than wide (HL 11.3-12.8 $\mathrm{mm}$, HW 11-11.2 $\mathrm{mm}$ in males); snout longer than eye (SL 4.9-5.5 mm, EL 3.2-3.4 mm); interorbital distance broader than internarial distance and upper eyelid (IN 2.5-2.9 mm, IUE 4-4.8 mm, UEW 2.3-2.6); tympanum distinct, smaller than half of eye diameter (TYD $1.9 \mathrm{~mm}$, EL 3.2-3.4 $\mathrm{mm}$ ); supratympanic fold indistinct. Fingers free of webbing; finger discs larger than those of toes, with circummarginal groove; tibia 5 times longer than wide (TL 15.5-15.6 mm, TW 3-3.4 mm); toes fully webbed; outer metatarsal tubercle absent; inner metatarsal tubercle elongate; dorsal skin smooth; dorsolateral fold absent; lateral sides without tubercles. Coloration in life: dorsum uniform green; sides of head and flanks yellow cream; lips white; tympanum cream; dorsal surface of limbs with white bars; webbing yellow; ventral surface white.

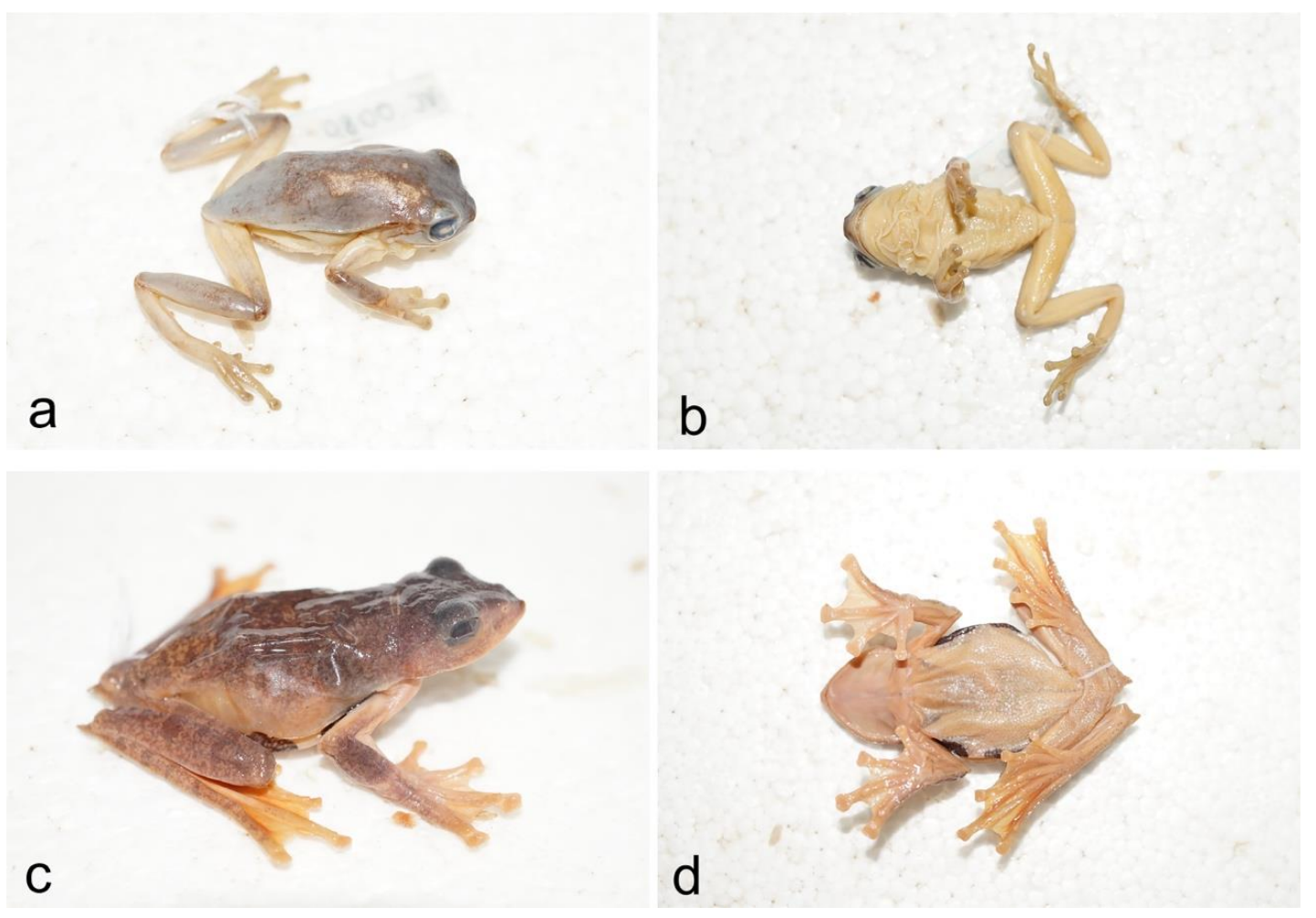

Figure 2. Hyla simplex (VPC.2018.80, adult female): a, Dorsal view and b, Ventral view; Rhacophorus rhodopus (VPC.2018.77, adult female): c, Dorsal view and d, Ventral view. [Photos by D.T. Le]

Natural history. Specimens were found between 19:00 and 20:00 on the ground. The surrounding habitat was mixed secondary forest consisting of small hardwood and shrub. 
Distribution. In Vietnam, this species has been recorded from Lang Son and Vinh Phuc in the North, southwards to Da Nang and Quang Nam provinces. Elsewhere, the species is found in northeastern Laos and southern China (Nguyen et al. 2009). This is the first record of $H$. simplex from Ha Noi City.

\section{Family RHACOPHORIDAE}

Rhacophorus rhodopus Liu \& Hu, 1960/Red-webbed treefrog (Fig. 2c, 2d)

Specimens examined $(n=3)$. Three adult males (VPC.2018.77-79) collected on 25 May 2017 near Tho Son Village, Soc Son WPF $\left(21.3174^{\circ} \mathrm{N}, 105.8094^{\circ} \mathrm{E}\right.$, elevation $\left.184 \mathrm{~m}\right)$.

Description. Morphological characters of the specimens from Ha Noi agreed with the description by Hecht et al. (2013) : SVL $37.3-40.9 \mathrm{~mm}$; head longer than wide (HL 13.1-15.3 mm, HW 12.3-13.8); snout pointed, longer than eye (SL 5.5-6.5 mm, EL 3.2-3.4 mm); canthus rostralis distinct; internarial distance wider than interorbital distance and upper eyelid (IN $3.5-4 \mathrm{~mm}$, IUE 4.1-6.6 mm, UEW 3.2-4.1 mm); tympanum distinct, about half of eye diameter (TYD 1.9-2.6 mm, EL 3.7$4.3 \mathrm{~mm}$ ); supratympanic fold indistinct; vomerine teeth present. Fingers almost fully webbed; finger I shorter than II; subarticular tubercles distinct; tibia 6 times longer than wide (TL 17.2-20.3 mm, TW 3-3.1 mm); toes fully webbed; tarsal fold present; outer metatarsal tubercle absent; inner metatarsal tubercle present; dorsal skin smooth; supratympanic fold distinct; cloacal dermal fringe present. Coloration in life: dorsum reddish brown with or without small black spots; large black blotches on axilla and flanks present; transverse bands on hind limbs absent or indistinct; ventral yellowish white; webbing of fingers and toes reddish orange.

Natural history. Specimens were collected at 20:30-23:00 on the ground. The surrounding habitat was mixed secondary forest consisting of small hardwood and shrub.

Distribution. In Vietnam, this is a widespread species, known from Lao Cai
Province in the North to Thua Thien - Hue Province in the Central. Elsewhere, R. rhodopus has been recorded from Northeastern India to Myanmar, northern Thailand, Laos, Vietnam, and southern China (Nguyen et al. 2009). This is a new record for Ha Noi City.

\section{REPTILIA}

Family AGAMIDAE

\section{Calotes versicolor (Daudin,} 1802/Oriental garden lizard (Fig. 3a, 3b)

Specimen examined $(\mathrm{n}=1)$. One adult female (VPC.2018.1T), collected on 25 May 2017 near Dong Lon sector, Nam Son Protective Forest $\left(21.1889^{\circ} \mathrm{N}, 105.4798^{\circ} \mathrm{E}\right.$, at an elevation of $341 \mathrm{~m}$ ).

Description. The morphological characters of the specimens agreed with the descriptions of Das (2010) and Gray (1845): Body moderate-sized. SVL $70.1 \mathrm{~mm}$; TaL $101.5+\mathrm{mm}$. Head distinct from neck; longer than wide (HL $22.4 \mathrm{~mm}$, HW $12.9 \mathrm{~mm}$ ); eyes and mental large; upper head scales larger than body scales; snout round; tympanum exposed; 2 spines above tympanum; supralabials 10; infralabials 10; scales between supraoculars 15 , between nostril 7; one spine behind the eye; neck spines longer than dorsum spines; length of biggest thorn in the neck $1.9 \mathrm{~mm}$. Dorsal scales, venter scales and limbs scales strongly keeled; hind limbs longer than fore limbs; lamellae 9 under finger I, 11(12) under finger IV; femoral pores absent; tail compressed; incomplete. The coloration of the preserved specimens is dorsum brownish above, upper side of head darker flecks, cheeks brighter, eye with radially directed dark lines, venter light, tail light brown.

Natural history. Specimens were found moving on the ground between 21:00 and 22:00. The surrounding habitat was mixed secondary forest consisting of small hardwood and shrub.

Distribution. In Vietnam, C. emma has previously been reported as occurring from Bac Giang and Thai Nguyen provinces southwards to Ba Ria-Vung Tau Province. 
Elsewhere, this species is found in India, southern China, Myanmar, Laos, norther
Thailand, Cambodia and Malaysia (Nguyen et al., 2009; Uetz et al., 2019).
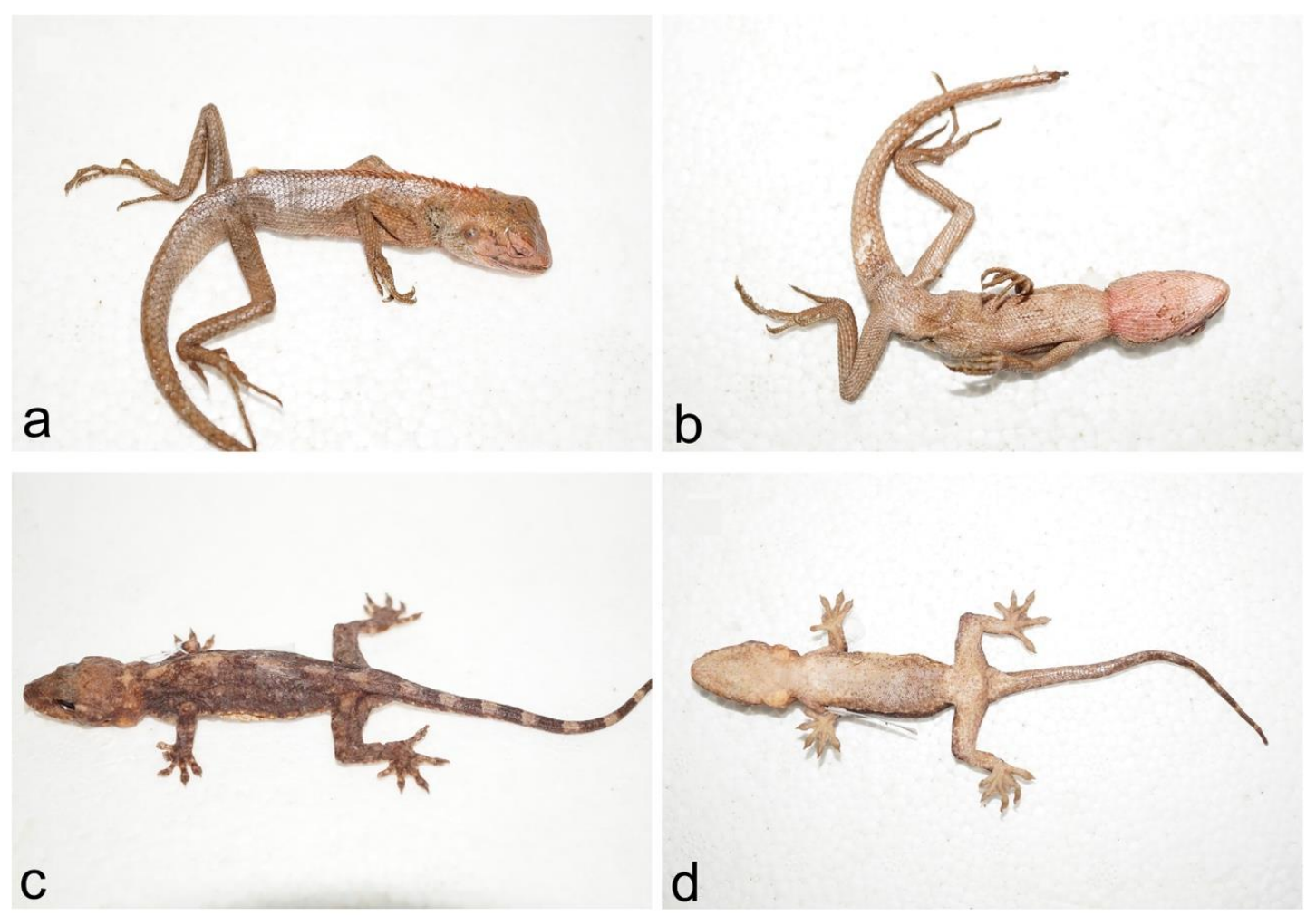

C

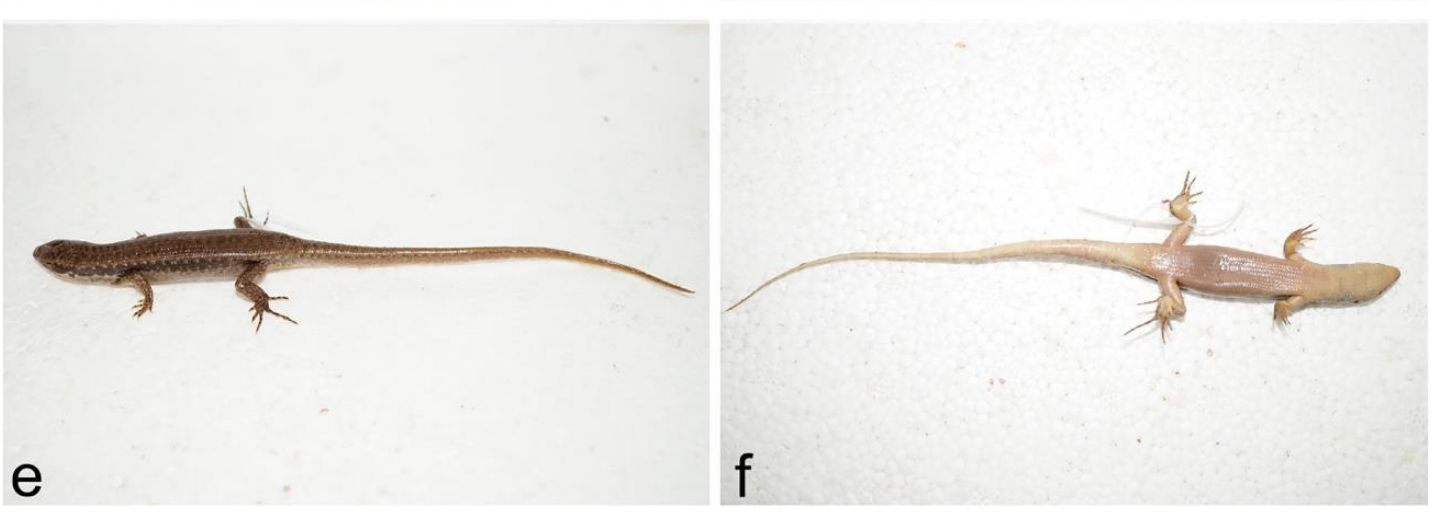

Figure 3. Calotes versicolor (VPC.2018.1T, adult female): a, Dorsal view and b, Ventral view; Gekko palmatus (VPC.2018.0048, adult male): c, Dorsal view and d, Ventral view;

Sphenomorphus indicus (VPC.2018.0066, adult male): e, Dorsal view and f, Ventral view. [Photos by D.T. Le]

Family GEKKONIDAE

Gekko palmatus Boulenger, 1907/Palm gecko (Fig. 3c, d)

Specimen examined $(\mathrm{n}=1)$. One adult female (VPC.2018.0048), collected on 25
May 2017 near Dong Lon sector, Nam Son Protective Forest $\left(21.1924^{\circ} \mathrm{N}, 105.4831^{\circ} \mathrm{E}\right.$, at an elevation of $291 \mathrm{~m}$ ).

Description. The morphological characters of the specimen agreed with the 
descriptions of Nguyen et al. (2013), Hecht et al. (2013): Moderate-sized (SVL $69.6 \mathrm{~mm}$, TaL $73.1 \mathrm{~mm}$ ). Head large, distinct from neck; longer than wide (HL $20 \mathrm{~mm}$, HW 15.2 $\mathrm{mm}$ ); internasal single, in contact with rostral; supralabials 13; infralabials 11; postcloacal tubercles 1; small scales contact chin shields 4. Dorsal scales small, midbody scales in rows 138 , granules surrounding dorsal tubercles 10 , scales in a line from mental to the front of cloacal slit 178; hind limbs longer than fore limbs; lamellae 12 under finger I, 13 under finger IV; 15 under toe I; tubercles present on upper surface of dorsum, hind limbs and tail base, absent on upper surface of fore limbs; subcaudals no enlarged; femoral pores and precloacal pores absent. The coloration of the preserved specimens is dorsal surface of head and dorsum greyish dark, with small light on neck areas and shoulder, dorsal tail with 8 light bands; tail, compressed, has light bands alternately with dark bands, 10 bands light on upper surface tail.

Natural history. The specimen was collected at 20:40, on a rock branch. The surrounding habitat was mixed secondary forest consisting of small hardwood and shrub.

Distribution. G. palmatus has previously been reported from Yen Bai, Lang Son, Bac Giang, Vinh Phuc, Quang Ninh, and Quang Binh provinces (Nguyen et al., 2009, 2013; Hecht et al., 2013). Elsewhere, the species is found in China (Luu, 2015; Uetz et al., 2019).

\section{Family SCINCIDAE}

\section{Sphenomorphus indicus 1853)/Indian forest skink (Fig. 3e, 3f)}

Gray,

Specimens examined $(\mathrm{n}=5)$. One subadult female (VPC.2018.0066), collected on 25 May 2017 near Dong Lon sector, Nam Son Protective Forest $\left(21.1904^{\circ} \mathrm{N}, 105.4856^{\circ} \mathrm{E}\right.$, at an elevation of $191 \mathrm{~m}$ ) and four adult females (VPC.2018.0051, 0052, 0065, 0067) collected on 25 May 2017 near Dong Lon sector, Nam Son Protective Forest $\left(21.1889^{\circ} \mathrm{N}\right.$, $105.4798^{\circ} \mathrm{E}$, at an elevation of $346 \mathrm{~m}$ ).

Description. The morphological characters of the specimens agreed with the descriptions by Smith, 1935; Ziegler, 2002;
Nguyen et al., 2011; and Hecht et al. (2013): Body moderate-sized (SVL $57.6 \mathrm{~mm}$, TaL $103.1 \mathrm{~mm}$ in the male and SVL 50.3-72.6 $\mathrm{mm}$, TaL $19.1{ }^{*}-116.7 \mathrm{~mm}$ in the females). Head smaller, distinguishable from neck; longer than wide (HL $9.9 \mathrm{~mm}$, HW $6.4 \mathrm{~mm}$ in the male and HL 9.8-17.5 mm, HW 5.5-10.3 $\mathrm{mm}$ in the females); eyes and ear-opening oval, present; snout small, obtuse; tympanum round, slightly to deeply sunk; loreals 2; supralabials 7; infralabials 7. Dorsal scales larges, smooth, midbody scales in 25 rows, median rows of dorsal scales distinctly widened; paravertebral scales 68 rows; 10 rows between two dark stripes on the sides; hind limbs longer than fore limbs; lamellae 7 under finger I, 9 under finger IV, 20 under toe IV; femoral pores and precloacal pores absent; tail strong. The coloration of the preserved specimens is dorsum dark above, neck and shoulders with light dorsolateral spots. The head has two black stripes on the sides from eyes to tail base. Tail compressed, venter, and under tail greyish black.

Natural history. The specimen was collected at 22:15, while resting on a rock near a small stream. The surrounding habitat was mixed secondary forest consisting of small hardwoods and shrub.

Distribution. S. indicus is a common species in Vietnam (Nguyen et al., 2009). However, this is the first record of the species from Soc Son WPF and from Hanoi City. Elsewhere, the species is found in India, Bhutan, China, Taiwan, Myanmar, Laos, Thailand, Cambodia, Malaysia, and Indonesia (Nguyen et al., 2009).

\section{Family COLUBRIDAE}

Elaphe taeniura Cope, 1861/Beauty snake (Fig. 4a, 4b)

Specimens examined $(\mathrm{n}=2)$. One adult female (VPC.2017.004) collected on 21 June 2017 and one adult female (VPC.2017.005) collected on 22 June 2017, near Hung Lon sector, Soc Son WPF $\left(21.1889^{\circ} \mathrm{N}, 105.4798^{\circ} \mathrm{E}\right.$, at an elevation of $341 \mathrm{~m}$ ). The morphological characters of the specimens agreed with the descriptions by Smith (1943), Nguyen (2007), and Das (2010). 


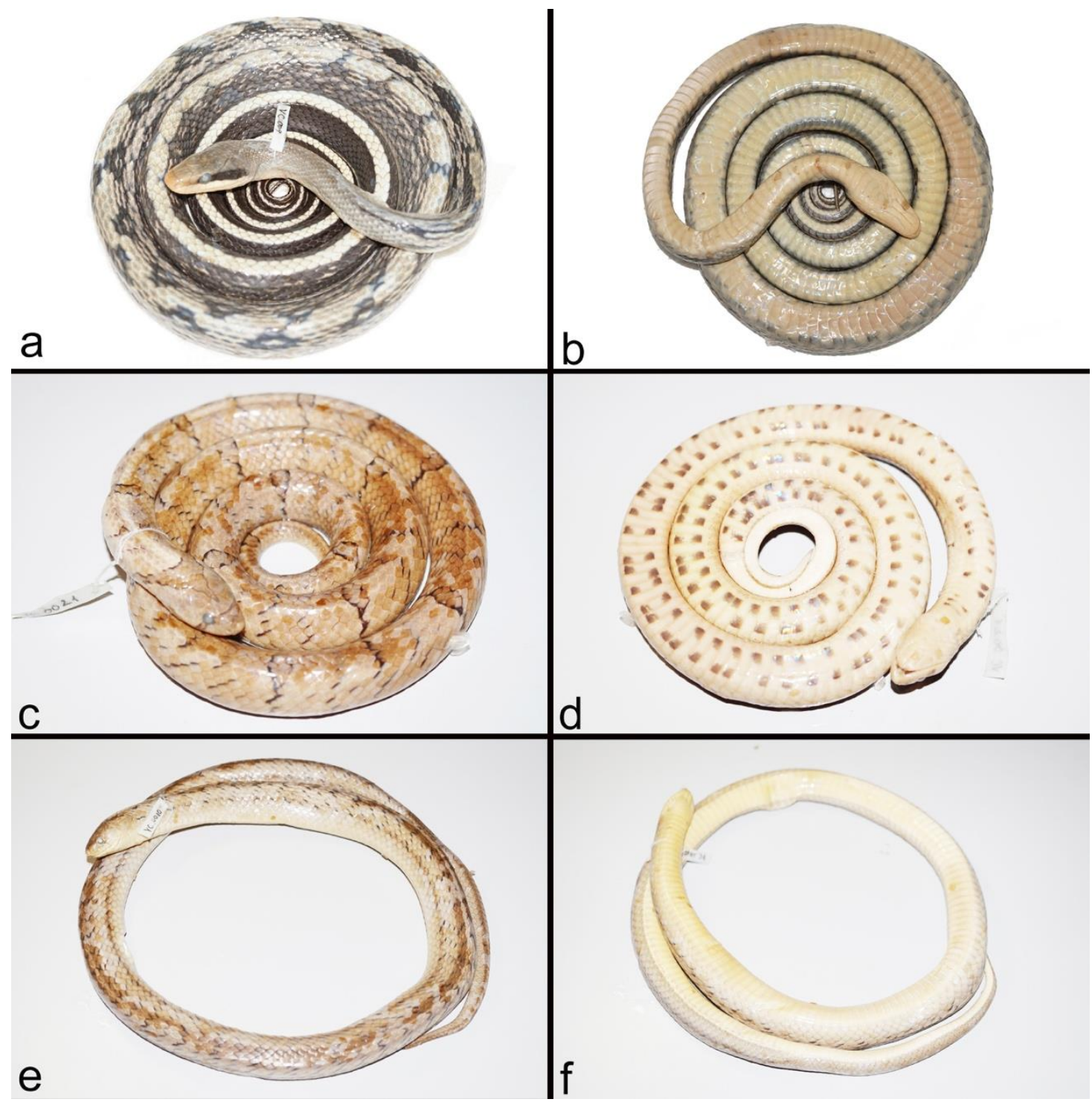

Figure 4. Elaphe taeniura (VPC.2017.004, adult female): a, Dorsal view and b, Ventral view; Oligodon chinensis (VPC.2018.0023, adult male): c, Dorsal view and d, Ventral view; O. taeniatus (VPC.2017.0010, adult female): e, Dorsal view and f, Ventral view. [Photos by D.T. Le]

Description. Body robust, subcylindrical (SVL 1350-1500 mm and TaL 372-424 mm in females). Head distinct from neck; snout obtuse; nostril lateral; eye large, pupil vertical. Head scalation complete, including paired internasals, prefrontals, and parietals, $1 / 1$ supraocular, and one frontal; 9/9 supralabials, $5^{\text {th }}$ and $6^{\text {th }}$ in contact with the eye, the $8^{\text {th }}$ scale largest; 10/10 infralabials, $1^{\text {st }}-6^{\text {th }}$ bordering chin shields. Dorsal scale rows 25-23-19, weakly keeled; scales of the outer dorsal scale row slightly enlarged; ventrals 261-270; subcaudals 108-121, paired; cloacal divided. Two black stripes from eye to angles of jaws; dorsum brownish above, four large blackish brown stripes, in $\mathrm{H}$-shape, on the anterior part of body; four black greyish stripes on tail. 
Natural history. The specimens were found between 21:00 and 22:00 while moving on the ground. The surrounding habitat was mixed secondary forest consisting of small hardwood and shrub.

Distribution. In Vietnam, E. taeniura had previously been reported from Lao Cai and Son La provinces in the north southwards to Gia Lai Province (Nguyen et al., 2009). Elsewhere, this species is found in Russia, China, Myanmar, Thailand, Laos, Malaysia, Japan (Nguyen et al., 2009; Uetz et al., 2019).

Remark. The specimens from Hanoi differ from the description of Das (2010) in having fewer ventrals (261-270 versus 271-305).

\section{Oligodon \\ chinensis 1888/Chinese kukri snake (Fig. 4c, 4d)}

Specimens examined $(\mathrm{n}=3)$. Two adult males (VPC.2018.0023, 0024) collected on 15 May 2018, near Dong Den Lake, Soc Son WPF $\left(21.1635^{\circ} \mathrm{N}, 105.4911^{\circ} \mathrm{E}\right.$, at an elevation of $115 \mathrm{~m}$ ) and one adult female (VPC.2018.0021) collected on 14 May 2018, near Dong Lon sector, Soc Son WPF $\left(21.1924^{\circ} \mathrm{N}, 105.4831^{\circ} \mathrm{E}\right.$, at an elevation of $285 \mathrm{~m})$. The morphological characters of the specimen agreed with the descriptions of Smith (1943) and Das (2010).

Description. Body robust, subcylindrical (SVL 530.2-559.2 $\mathrm{mm}$ and TaL 116.2-150 $\mathrm{mm}$ in males; SVL $498.4 \mathrm{~mm}$ and TaL 119.8 $\mathrm{mm}$ in the female). Head not distinct from neck; snout obtuse; nostril lateral; eye small, pupil vertical. Head scalation complete, including paired internasals, prefrontals, and parietals, 1/1 supraocular, and one frontal; $8 / 8$ supralabials, $4^{\text {th }}$ and $5^{\text {th }}$ in contact with the eye, the $7^{\text {th }}$ largest; $8 / 8$ infralabials, $1^{\text {st }}-4^{\text {th }}$ bordering chin shields. Dorsal scale rows 1717-15, smooth; ventrals 174-186; subcaudals 53-62, paired; cloacal single. Dorsum greyish brown and 12 spots constantly narrow, elongated dark brown, edged with black.

Natural history. The specimens were found moving on the ground between 19:00 and 20:30. The surrounding habitat was mixed secondary forest consisting of small hardwood and shrub.
Distribution. In Vietnam, O. chinensis had previously been reported from Lao Cai and Bac Kan provinces in the North southwards to Gia Lai Province (Nguyen et al., 2009). Elsewhere, this species is found in China (Nguyen et al., 2009; Uetz et al., 2019).

\section{Oligodon taeniatus Günther, 1861/Striped kukri snake (Fig. 4e, 4f)}

Specimen examined $(\mathrm{n}=1)$. An adult female (VPC.2017.0010) collected on 23 June 2017 near Tho Son Village, Soc Son WPF $\left(21.1904^{\circ} \mathrm{N}, 105.4856^{\circ} \mathrm{E}\right.$, at an elevation of $184 \mathrm{~m})$. The morphological characters of the specimen agreed with the descriptions by Smith (1943), David et al. (2008), Das (2010), and Campden - Main (1970).

Description. Body larger, subcylindrial (SVL $788 \mathrm{~mm}$; TaL $166 \mathrm{~mm}$ ). Head not distinct from neck; snout obtuse; nostril lateral; eye large, pupil vertical. Head scalation complete, including paired internasals, prefrontals, and parietals, 1/1 supraocular, and one frontal; 9/9 supralabials, $4^{\text {th }}$ and $5^{\text {th }}$ in contact with the eye, the $8^{\text {th }}$ largest; $9 / 9$ infralabials, $1^{\text {st }}-4^{\text {th }}$ bordering chin shields. Dorsal scale rows 19-19-17, smooth; ventrals 171; subcaudals 54, paired; cloacal single. Dorsum brownish grey; dorsal scales edged with dark brown posteriorly; with four dark brown longitudinal stripes and a light paravertebral 1 stripe.

Natural history. The specimen was collected at 20:30 while resting on the ground, in the second forest.

Distribution. In Vietnam, O. taeniatus had previously been reported from Ha Giang and Cao Bang provinces in the North southwards to Kien Giang Province (Nguyen et al., 2009). Elsewhere this species is found in Laos, Thailand and Cambodia (Nguyen et el., 2009; Uetz et al., 2019).

Remarks. The specimen from Hanoi differs from the descriptions of David et al. (2008) and Das (2010) in having more ventrals (171 versus 146-165) and subcaudals (54 versus $31-48$ ).

Family NATRICIDAE 
Sinonatrix percarinata Boulenger, 1899/Eastern water snake (Fig. 5a, 5b)

Specimens examined $(\mathrm{n}=2)$. One adult male (VPC.2018.0025) collected on 16 May 2018, near Dong Den Lake, Soc Son WPF $\left(21.1635^{\circ} \mathrm{N}, 105.8185^{\circ} \mathrm{E}\right.$, at an elevation of $115 \mathrm{~m})$ and one adult female
(VPC.2018.0022) collected on 14 May 2018 near Dong Lon sector, Soc Son WPF $\left(21.1923^{\circ} \mathrm{N}, 105.4836^{\circ} \mathrm{E}\right.$, at an elevation of $243 \mathrm{~m})$. The morphological characters of the specimen agreed with the descriptions by Smith (1943), Nguyen (2007), Das (2010), Le et al. (2015), and Le et al. (2018).

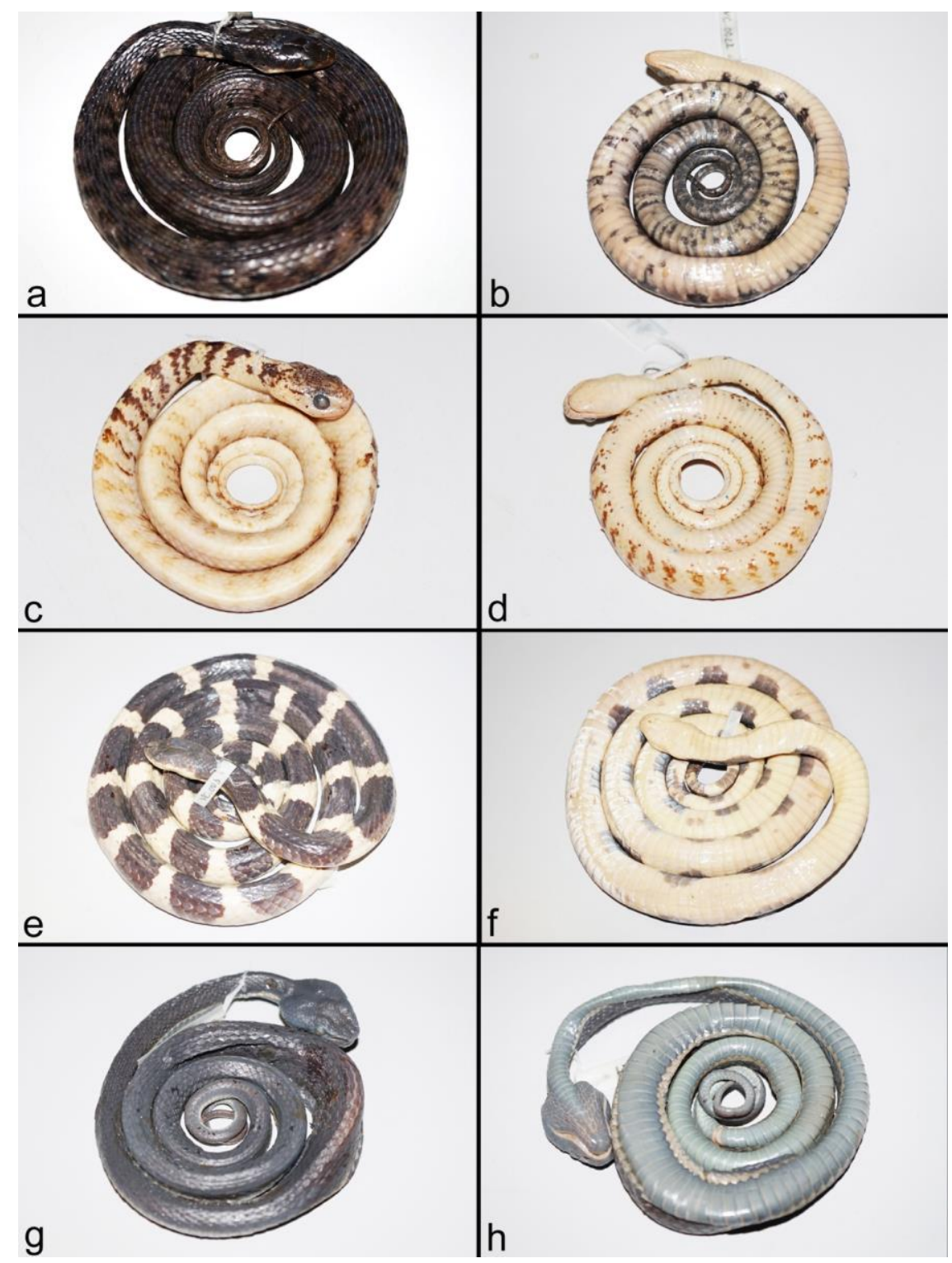

Figure 5. Sinonatrix percariata (VPC.2018.0022, adult female): a, Dorsal view and b, Ventral view; Pareas carinatus (VPC.2018.0034, a juvenile): c, Dorsal view and d, Ventral view; Bungarus candidus (VPC.2017.0003, adult female): e, Dorsal view and f, Ventral view; Trimeresurus stejnegeri (VPC.2017.0017, a juvenile): g, Dorsal view and h, Ventral view. 
Description. Body robust; SVL $492 \mathrm{~mm}$ female, $512.6 \mathrm{~mm}$ male; TaL $197.4 \mathrm{~mm}$ female, $174.9 \mathrm{~mm}$ male. Head distinct from neck; snout obtuse; nostril lateral; eye large, pupil round. Head scalation complete, including paired internasals, prefrontals, and parietals, 1/1 supraocular, and one frontal; rostral wider than high; $9 / 9$ supralabials, $4^{\text {th }}$ and $5^{\text {th }}$ in contact with the eye, the $7^{\text {th }}$ largest; 10 infralabials, $1^{\text {st }}-5^{\text {th }}$ bordering chin shields. Dorsal scale rows 19-19-17, keeled, the first scale row smooth, scales of the outer scale row enlarged; ventrals 130-135; subcaudals 77-97, all paired; cloacal divided. Dorsal surface of head, body and tail olive grey, with light-edged black bars on flanks, broad dorsally, becoming narrower laterally, venter yellowish cream anteriorly, with small black speckles posteriorly; subcaudals dark grey with black spots.

Natural history. The specimens were collected between 17:00 and 19:00, while resting or foraging on trees above small streams. The surrounding habitat was mixed secondary forest consisting of small hardwoods and shrub.

Distribution. In Vietnam, $S$. percarinata had previously been reported from Lao Cai Province in the North southwards to Dong Nai Province (Nguyen et al., 2009; Le et al., 2018). Elsewhere, this species is found in India, China, Taiwan, Myanmar, Laos, and Thailand (Nguyen et al., 2009; Uetz et al., 2019).

\section{Family PAREATIDAE}

Pareas carinatus Boie, 1828/Keeled slug snake (Fig. 5c, 5d)

Specimen examined $(\mathrm{n}=1)$. One juvenile (VPC.2018.0034) collected on 19 May 2018, near Tho Son Village, Soc Son WPF $\left(21.1904^{\circ} \mathrm{N}, 105.4856^{\circ} \mathrm{E}\right.$, at an elevation of $184 \mathrm{~m})$. The morphological characters of the specimen agreed with the descriptions of Smith (1943), Nguyen (2007), Das (2010), and Le et al. (2014).

Description. Body slender (SVL 271.8 $\mathrm{mm}$; TaL $85.1 \mathrm{~mm}$ ). Head distinct from neck; snout obtuse; nostril lateral; eye small, pupil round. Head scalation complete, including paired internasals, prefrontals, and parietals, 1/1 supraocular, and one frontal; rostral wider than high; 7/7 supralabials, separated from the eye, the $7^{\text {th }}$ largest; $8 / 8$ infralabials, $1^{\text {st }}-4^{\text {th }}$ bordering chin shields. Dorsal scale rows 1515-15, smooth, vertebral scales not enlarged; ventrals 186; subcaudals 93, all paired; cloacal single. Dorsum bright brown, with small transverse black bars; head grey; ventral light cream; tail dark grey.

Natural history. The specimen was collected at 21:15, while resting on a tree near a small stream. The surrounding habitat was mixed secondary forest consisting of small hardwoods and shrub.

Distribution. In Vietnam, $P$. carinatus had previously been reported from Vinh Phuc Province in the North southwards to Tay Ninh Province (Nguyen et al., 2009). Elsewhere, this species is found in China, Myanmar, Laos, Thailand, Cambodia, Malaysia, and Indonesia (Nguyen et el., 2009; Uetz et al., 2019).

\section{Family ELAPIDAE}

Bungarus candidus Linnaeus, 1758/Blue

\section{Krait (Fig. 5e, 5f)}

Specimen examined $(\mathrm{n}=1)$. An adult female (VPC.2017.003) collected on 21 June 2017, near Hung Lon sector, Soc Son WPF $\left(21.1889^{\circ} \mathrm{N}, 105.4798^{\circ} \mathrm{E}\right.$, at an elevation of $341 \mathrm{~m})$. The morphological characters of the specimen agreed with the descriptions by Smith (1943), Nguyen (2007), and Das (2010).

Description. Body robust; SVL 1082.4 $\mathrm{mm}$; TaL $169.6 \mathrm{~mm}$. Head distinct from neck; snout obtuse; nostril lateral; eye small. Head scalation complete, including paired internasals, prefrontals, and parietals, 1/1 supraocular, and two frontals; rostral wider than high; loreal absent; 7/7 supralabials, $3^{\text {rd }}$ and $4^{\text {th }}$ in contact with the eye, the $5^{\text {th }}$ and $6^{\text {th }}$ largest; $7 / 7$ infralabials, $1^{\text {st }}-3^{\text {rd }}$ bordering chin shields. Dorsal scale rows 16-15-15, smooth, vertebral scales enlarged; ventrals 216; subcaudals 51, undivided; cloacal single.

Ecological notes. The specimen was collected at 20:30, while moving on the ground, near the residential area. 
Distribution. In Vietnam, B. candidus had previously been reported from Hoa Binh Province in the North southwards to Tay Ninh Province (Nguyen et al., 2009). Elsewhere, this species is found in Laos, Thailand, Cambodia, Malaysia, Singapore and Indonesia (Nguyen et el., 2009; Uetz et al., 2019).

\section{Family VIPERIDAE}

Trimeresurus stejnegeri Schmidt, 1925/Bamboo pit viper (Fig. 5g, 5h)

Specimen examined $(\mathrm{n}=1)$. One juvenile (VPC.2017.0017) collected on 26 June 2017 near Dong Lon sector, Soc Son WPF $\left(21.1924^{\circ} \mathrm{N}, 105.4831^{\circ} \mathrm{E}\right.$, at an elevation of $285 \mathrm{~m})$. The morphological characters of the specimen agreed with the descriptions of Smith (1943), Campden-Main (1970), and Nguyen (2007).

Description. Size small; SVL $407.9 \mathrm{~mm}$; TaL $52.5 \mathrm{~mm}$. Head in triangle shape, distinct from neck; snout obtuse; nostril dorsolateral; eye large. Upper head scales smooth, irregular, scarcely increasing in size anteriorly, loreal absent; $1 / 1$ preocular; $1 / 1$ postocular; $10 / 10$ supralabials; $12 / 12$ infralabials; dorsal scale rows 21-21-15, feebly keeled; ventrals 168; cloacal single; subcaudals 74, paired. Dorsum green above, ventral is the lighter than dorsum; a distinct whitish yellow stripe on the lower part of flank; tail black.

Ecological notes. The specimen was collected at 22:00, while resting on a tree branch near a small stream. The surrounding habitat was mixed secondary forest consisting of small hardwood and shrub.

Distribution. In Vietnam, T. stejnegeri had previously been reported from Lao Cai and Ha Giang provinces in the North southwards to Da Nang Province (Nguyen et al., 2009). Elsewhere, this species is found in China, Taiwan, and Myanmar (Nguyen et al., 2009; Uetz et al., 2019).

\section{DISCUSSION}

Based on our field work in 2017 and 2018, 10 species of amphibians and 32 species of reptiles were recorded from Soc Son WPF, in which, two species of amphibians (Hyla simplex, Rhacophorus rhodopus) and ten species of reptiles (Calotes versicolor, Gekko palmatus, Sphenomorphus indicus, Elaphe taeniura, Oligodon chinensis, O. taeniatus, Sinonatrix percarinata, Pareas carinatus, Bungarus candidus, and Trimeresurus stejnegeri) are recorded for the first time from Hanoi City. Among 42 recorded species, two species (Naja atra and Ophiophagus hannah) are listed in the IUCN Red List (2020), five species (Coelognathus radiatus, Ptyas korror, Bungarus fasciatus, Naja atra, and Ophiophagus hannah) are listed in the Vietnam Red Data Book (2007), and two species (Naja atra, and Ophiophagus hannah) are listed in the Governmental Decree No 06/2019/ND-CP. Although the forest in Soc Son WPF harbors a considerable number of endemic and rare species, its biodiversity is currently threatened due to conversion of forest land for other uses. Additional surveys are required to obtain further data about the actual biodiversity of this forest.

Acknowledgements: We are grateful to the directorates of the Forest Protection Department of Soc Son WPF for support of our field work. We thank Tinh Xuan Dao and Anh Tuan Dao (local people) for their assistance in the field. We thank Truong Quang Nguyen (Institude of Ecology and Biological Resources, VAST), Anh Ngoc Dao and Yen Thi Do (Hanoi National University of Education) for laboratory assistance, Tuan Anh Tran (Institude of Ecology and Biological Resources, VAST) for providing the map.

\section{REFERENCES}

Campden-Main S. M., 1970. A field guide to the snakes of South Vietnam. Smithsonian Institution, Washington, $114 \mathrm{pp}$.

Das I., 2010. A field guide to the Reptiles of South-East Asia. New Holland Publishers, London, United Kingdom, 376 pp.

David P., Vogel G., van Rooijen J., 2008. A revision of the Oligodon taeniatus (Günther, 1861) group (Squamata: Colubridae), with the description of three 
new species from the Indochinese Region. Zootaxa, 1965: 1-49.

Dowling H. G., 1951. A proposed standard system of counting ventrals in snakes. British Journal of Herpetology, 1(5): 97-99.

Gray J.E., 1845. Catalogue of the specimens of lizards in the collection of the British Museum. Trustees of die British Museum/Edward Newman, London: xxvii +289 pp.

Hanoi City People's Committee, 2008. Decision No. 2100/QD-UBND dated on May 29, 2008, on approval of the project to adjust forest planning in Soc Son District. (in Vietnamese).

Hecht V., Pham C. T., Nguyen T. T., Nguyen T. Q., Bonkowski M., Ziegler T., 2013. First report on the herpetofauna of Tay Yen $\mathrm{Tu}$ Nature Reserve, northeastern Vietnam. Biodiversity Journal, 4(4): 507-552.

IUCN, 2020. The IUCN Red List of Threatened Species, Version 2020.2. http://www.iucnredlist.org [accessed: 18/11/2020]

Le D. T., Dao A. N., Pham D. T., Ziegler T., Nguyen T. Q., 2018. New records and an updated list of snakes from Yen Bai Province, Vietnam. Herpetology Notes, 11: 101-108.

Le D. T., Nguyen S. L. H., Pham C. T., Nguyen T. Q. (2014). New records of snakes (Squamata: Serpentes) from Dien Bien Province. Journal of Biology, 36(4): 460-470.

Le D. T., Pham A. V., Pham C. T., Nguyen S. H. L., Ziegler T., Nguyen T. Q., 2015. Review of the genus Sinonatrix in Vietnam with a new country record of Sinonatrix yunanensis Rao et Yang, 1998. Russian Journal of Herpetology, 22(2): 84-88.

Luu V. Q., Calame T., Nguyen T. Q., Le M. D., Ziegler T., 2015. Morphological and molecular review of the Gekko diversity of Laos with descriptions of three new species. Zootaxa, 3986(3): 279-306.
Marsili L., Casini S., Mori G., Ancora S., Bianchi N., D'Agostino A., Ferraro M., Fossi M.C., 2009. The Italian wall lizard (Podarcis sicula) as a bioindicator of oil field activity. Science of the Total Environment, 407: 3597-3604.

Nguyen S. V., 2007. Fauna of Vietnam: Serpentes. Hanoi, Vietnam, Science and Technics Publishing House. 247 pp. (in Vietnamese).

Nguyen S. V., Ho C. T., Nguyen T. Q., 2005. A Checklist of the Amphibians and Reptiles of Vietnam. Agriculture Publishing House, Hanoi, Vietnam.

Nguyen S. V., Ho C. T., Nguyen T. Q., 2009. Herpetofauna of Vietnam. Frankfurt am Main, Germany, Edition Chimaira. 768 pp.

Nguyen T. Q., Wang Y-Y., Yang Y-H., Lehmann T., Le M. D., Ziegler T. \& Bonkowski M., 2013. A new species of the Gekko japonicus group (Squamata: Sauria: Gekkonidae) from the border region between China and Vietnam. Zootaxa, 3652: 501-518.

Orlov N. L., Murphy R. W., Ananjeva N. B., Ryabov S. A., Ho C.T., 2002. Herpetofauna of Vietnam, a checklist. Part I. Amphibia. Russian Journal of Herpetology, 9(2): 81-104.

Simmons J. E., 2002. Herpetological collecting and collections management (Revised edition). Society for the Study of Amphibians and Reptiles, Herpetological Circular, 31: 1-153.

Smith M. A., 1935. The fauna of British India, including Ceylon and Burma. Reptiles and Amphibia, Vol. II. Sauria. Taylor and Francis, London, 440 pp.

Smith M. A., 1943. The Fauna of British India, Ceylon and Burma, Including the Whole of the Indo-Chinese Subregion. Reptilia and Amphibia. Volume III. Serpentes. London, United Kingdom, Taylor and Francis, 583 pp.

The Goverment of Vietnam, 2019. Decree No 06/2019/ND-CP of the Government of Vietnam on management of threatened 
and rare wild plants and animals, dated on 22 January 2019. Ha Noi: 44 pp.

Tran K., Ho C. T., Nguyen S. V., Pham T., 2007. Reptiles and amphibians. In: Vietnam Red Data Book. Part 1. Animals, p. 219-276. Dang T.N., Tran K., Dang H.H., Nguyen C., Nguyen T.N., Nguyen Y.H., Dang D.T., Eds., Hanoi, Vietnam, Natural Science and Technology Publishing House.
Uetz P., Freed P., Hošek J., Eds., 2020. The Reptile Database. Available at http://reptiledatabase.reptarium.cz/search.php [accessed: 19/04/2020]

Ziegler T., 2002. Die Amphibien und Reptilien eines Tiefland-feuchtwaldSchutzgebietes in Vietnam. Natur \& Tier Verlag, Münster. 